\title{
ERRATA
}

\section{Notification that New Names and New Combinations Have Appeared in IJSB}

Volume 43, no. 3, p. 625: "Paracoccus pantotropha pro synon. Thiospaera pantotrophica" should read "Thiosphaera pantotropha pro synon. Paracoccus denitrificans."

\section{Eubacterium saphenus sp. nov., Isolated from Human Periodontal Pockets}

HIROYUKI UEMATSU, FUTOSHI NAKAZAWA, TETSURO IKEDA, AND ETSURO HOSHINO

Department of Oral Microbiology, Niigata University School of Dentistry, Gakkocho-dori 2, Niigata 951, Japan

Volume 43, no. 2, p. 302 to 304: "Eubacterium saphenus" should read "Eubacterium saphenum."

\author{
Natronobacterium vacuolata sp. nov., a Haloalkaliphilic Archaeon Isolated \\ from Lake Magadi, Kenya \\ WANJIRU E. MWATHA AND WILLIAM D. GRANT \\ Department of Botany, Kenyatta University, Nairobi, Kenya, and Department of Microbiology, \\ University of Leicester, P.O. Box 138, Leicester LE1 9HN, United Kingdom
}

Volume 43, no. 3, p. 401 to 404: "Natronobacterium vacuolata" should read "Natronobacterium vacuolatum."

\section{Isolation and Characterization of Methanohalophilus portucalensis sp. nov. and DNA Reassociation Study of the Genus Methanohalophilus}

DAVID R. BOONE, INDRA M. MATHRANI, YITAI LIU, JOSÉ A. G. F. MENAIA, ROBERT A. MAH, AND JANE E. BOONE

Departments of Environmental Science and Engineering and Chemical and Biological Sciences, Oregon Graduate Institute of Science \& Technology, 19600 N.W. von Neumann Drive, Beaverton, Oregon 97006-1999; School of Public Health, University of California, Los Angeles, California 90024; and Laboratório Nacional de Engenharia e Tecnologia Indústrial, Estrada das Palmeiras, 2745 Queluz, Portugal

Volume 43, no. 3, p. 431, Table 1: The DSM accession number for Methanohalophilus portucalensis Z-7405 should read “5703." 